Предраг Мутавџић

Универзитет у Београду

Филолошки факултет

Катедра за неохеленске студије

predrag.mutavdzic@fil.bg.ac.rs

Мерима Кријези

Универзитет у Београду

Филолошки факултет

Катедра за албанологију

merima.krijezi@fil.bg.ac.rs
УДК 811.18'37: 811.14'37:811.163.41'37

https://doi.org/10.18485/slavistika.2020.24.1.20

Оригинални научни рад примљено 30.04.2020.

прихваћено за штампу 21.05.2020.

\title{
О ЗООНИМИМА УВРЕДЉИВОГ САДРЖАЈА У АЛБАНСКОМ, ГРЧКОМ И СРПСКОМ
}

Зооними су важан лексички сегмент, сусрећу се у комуникацији у најразличитијим говорним ситуацијама као квалификатори физичких, псхихолошких, моралних и интелектуалних одлика. У раду сагледавамо зоониме контрастивно и компаративно у три балканска језика, грчком, албанском и српском, настојећи да их у најосновнијим цртама класификујемо. Како носе конотацију посебне карактеризације и дескрипције, зооними непосредно откривају како говорници посматрају себе и друге.

Кључне речи: зооними, увреде, карактеризација, класификација, фразеологизми, грчки, албански, српски.

Zoological idiomatic expressions constitute an important lexical segment and are found in communication in a variety of discourse situations as qualifiers of physical, psychological, moral and intellectual traits. In this paper we examine zoological phraseologisms from the contrastive and comparative perspective in three contemporary Balkan languages, Greek, Albanian and Serbian, while attempting to broadly classify them. Since these phraseologisms carry a connotation of a specific character and description, they directly reveal the manner in which speakers perceive both themselves and others.

Keywords: zoonyms, insults, characterization, classification, idiomatic expressions, Albanian, Greek, Serbian.

\section{1. Увод}

Човек зависи од животиња и у ланцу исхране и непосредно (служе му као радна снага). Ова исконска веза почива на сложеним односима између човека и животиња (домаћих и дивљих) успостављеним током људске историје. Свако друштво развило је специфичне односе према животињама из окружења, што се у језицима да̂ сагледати. Домаће животиње су оличење низа људских особина неуочених код дивљих, а од давнина дивље животиње красе магично-мистичне, натприродне, особине непрепознатљиве код домаћих. Ова два „царства животиња“ оделита су и ретко се мешају. Изузетак су зодијаци: налазећи се и у таквим духовним апстракцијама, одабране домаће и дивље животиње стекле су космичке моћи, што их је приближило божанствима. Нека су божанства представљана само као животиње (Маје су приносиле људске жртве 
„горостасном кипу крокодила, за кога се веровало да представља Ицамну1“; O`Konel-Eri 2007: 30), поједина се претварају у неку животињу르, нека су божанства полуљуди-полуживотиње (египатски Анубис, с главом шакала, или Сфинга, с лављим телом), извесна су пратиоци божанстава (кобра Шиве). У грчкој митологији голубица је сагледавана као пратиља Афродите и као симбол људске душе: на урнама се приказује да „пије воду из вазе која симболизује фонтану сећања“" (Lavedan 1931: 258). Животињама, без обзира на културу и традицију, припадају сва три нивоа - свет небеса (узвишеног), свет реалног (овоземаљског) и свет оностраног (мрачног) - а свака од њих има функцију и место у свом свету кога ретко напушта. Отуда „изучавање животиња у језичком и културном контексту заједно с узајамним односима човека и животиња чини предмет интересовања културне зоологије као дела лингвокултурологије“ (Јовановић 2018: 56).

\section{2. Циљ и методологија рада, корпус}

Рад је усмерен на називе животиња у три балканска језика, грчком, албанском и српском, употребљених самостално или у фразеологизмима, који служе омаловажавању и вређању. Називамо их зоонимски негативни квалификатори. Овај вид лексичке фразеологије као језичка универзалија захвата до $15 \%$ укупне фразеологије ма ког језика (Moon 1998: 56; Ellis 1997: 133-143). Лексички, структурно и семантички, фразеологизми са зоонимима чине подсистем у целокупном лексичком систему сваког језика, бројни су и разноврсни. У раду:

а) пружамо листу најчешћих зоонимских негативних квалификатора у сва три језика. Контрастивно и компаративно их упоређујемо с одговарајућим еквивалентима у циљним језицима. Због компаративног приступа сваки од разматраних језика је и полазан и циљан, сходно смеру кретања;

б) класификујемо зоонимске негативне квалификаторе у односу на то коме се упућују или какву метафоричку функцију и семантичку поруку носе;

в) примере на албанском и грчком дајемо као глосе;

г) примери са звездицом чине категорију нулте структурно-семантичке еквиваленције;

д) разматрамо и пословице као структурно блиске фразеологизмима.

Корпус чине штампани и online једнојезични и двојезични речници на сва три језика (њихов списак је на крају рада). Ослонили смо се и на резултате добијене преко претраживача Google који су секундарна провера употребе и значења како свих забележених зоонима тако и фразеологизама са њима као кључном речју.

\footnotetext{
${ }^{1}$ Врховно божанство Маја.

2 Преображен у белог бика, Зевс отима Европу коју силује као орао. Прерушен у орла, краде Ганимеда са тројанске равнице.
} 
Иако лексичка семантика није основно поље наших интересовања, можемо рећи да су консултовани речници релативно подударни када је реч о зоонимима као лексичким јединицама те да нуде увид у широко фразеолошко и семантичко поље њихових значења. Разматрани зоонимски слој у сва три језика има и додирних тачака, што се посебно огледа у заступљености назива свих познатих животиња (домаћих и дивљих) са балканског географског ареала, али истовремено исказују се и бројне разлике, понајпре што у сваком језику понаособ само одабрани зооними учествују у грађењу фразеологизама или се употребљавају као самосталне лексеме (обично у узвичним реченицама). Запажене су разлике и неподударности у семантичком тумачењу метафоричних значења зоонима и у укупном броју фразеологизама који варира од језика до језика - у том погледу албански предњачи у односу на српски и грчки. Примећен је и неједнак број фразеологизама с истим зоонимом у сва три језика: у српском зооним вук гради 12, у грчком $\lambda \hat{\kappa} \kappa o \varsigma ~ 13$, а у албанском ujk чак 27 фразеологизама, укључујући и пословице. У односу на српски и грчки, у албанском безмало сваки зооним из оквира познатог традиционалног зоонимског фонда учествује у грађењу фразеолошких квалификатива и/или пословица. Тако се зооним çakall (= шакал) фразеолошки налази у склопу именског предиката означавајући похлепног човека, а као кључна лексема формира две пословице ${ }^{3}$. У грчком иста лексема ( $\tau \sigma \alpha \kappa \alpha ́ \lambda \iota)$ налази се фразеолошки само у именском делу предиката као квалификатив, означавајући „зверку“, виспреног и способног човека, и не твори пословице.

Тек поједини зооними поседују своје дублете (пас/иукела, кою/ат, магараи) сивоња, змија/zуja; gomar/murro, sorrë/stërqokë, bretkosë/zhabë, kalë/at, gjarpër/

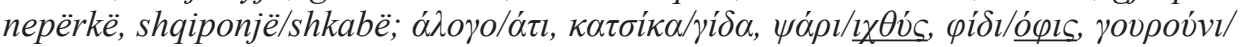
zoí $\rho$ ). Како се (подвучени) дублети у грчком употребљавају у стручном речнику и у ученом језику и стилу, превасходно у устаљеним фразеолошким конструкцијама, нисмо их разматрали у раду, а када је реч о дублетима у српском и албанском, узети су у обзир уколико носе негативно квалификативно значење.

Ексцерпирани су само они фразеологизми са зоонимима који носе негативну квалификацију. У разматање су узети и зооними као самосталне лексеме под условом да њихова употреба у језику то дозвољава (обично у вокативу, а у албанском и када се зооним налази уз глагол у оптативу). У сваком разматраном језику постоје зооними који се у другом језику/другим језицима не употребљавају као негативни квалификатори.

\section{3. Неколико речи о животињама у језику}

Усвајањем матерњег и учењем страног језика уче се називи животиња и упознају се њихове одлике, спољашње и унутрашње карактеристике, као „етикете“ које су очувани културно-психолошки, митолошки и друштвени стере-

\footnotetext{
${ }^{3}$ Kur s'ke arë në mal, pse bën dava me çakejtë (= ,ако немаш њиве на планини, што се тужиш са шакалима“") = „не мешај се у туђа посла/гледај своја посла“, çakalli bëri kërdinë, ujku i doli nami (= „шакал је учинио покољ, вук је за то окривљен“") = „извући дебљи крај/ свалити кривицу на другога“.
} 
отипи додељени животињама путем човековог пажљивог посматрања начина живота и опхођења сваке животиње у природи или у човековом непосредном окружењу. Установивши сличности/идентичности између њихових образаца понашања и човекових, човек је приписао свакој њему познатој животињи одређене психолошке, моралне и карактерне одлике чиме је она постала „обрнуто огледало“ човека. Тек је у појединим случајевима могуће говорити о томе да је човек животињско понашање пренео на свој свет, попут лексеме стампедо.

Зооними су или „речи са значењем каквог предмета, разуме се без експресивне маркираности (коњ - гимнастичка справа), или речи са значењем лица одређених особина (гуска - глупа женска особа) [чиме] ова метафоризација даје експресивно маркирану секундарну лексичку јединицу“ (Гортан-Премк 2005: 115), а преко метонимије постају и симболи (орлови - надимак фудбалске репрезентације Србије). Део су лексике сваког језика која, иако се традиционално сагледава као „spisak stvari, pojmova i odnosa koji postoje u svetu“, ипак недвосмислено „оdražava materijalnu i duhovnu kulturu pojediničnih ljudskih zajednica, ne svet u celini“" (Bugarski 1983: 172). У дискурсу, зооними су попут медијума - то су посебни продужеци наших чула, топли или хладни (McLuhan 1994: 22-32), сходно поруци коју носе: као негативни квалификатори чине групу хладних медијума, али на пољу афективности то нису. Заправо, то је таква врста језичког квалификативног коิда који је не само мотивисан да укаже на „сличности са циљним појмом [које] нису увек апсолутне и комплетне“ (Драгићевић 2010: 148), него је и временом друштвено прихваћен као вид неформалне комуникације и обраћања, што значи да је „od najveće važnosti šta se postiže onim što je rečeno i kako se to uklapa u kulturne konvencije date govorne zajednice“ (Bugarski 2005: 35). Зато „се семантичке реализације зоонима делом темеље на искуству и суживоту с различитим животињама, али могу бити и резултат устаљеног доживљаја животињског понашања које се ослања на културне предрасуде“, при чему треба назначити да „се пренос назива животиња на човекове одређене особине одиграва на основу интерпретације њиховог станишта, изгледа, понашања и односа са човеком као таквих да кореспондирају са непожељним особеностима карактеристичним за човека (Новокмет 2017a: $540,544)$. Односно, „ако аутор за X каже да је Y, а знамо да Ү није X, онда морамо замислити свет у коме X је Y, прихватајући његове основе за то“ (Miller 1993: 367).

Зооними, посебно у фразеологизмима, „сматрају се метафоричким изразима који интегришу културу људи и њихове особене облике комуникације, пружајући им посебну боју“ (Budny 2017: 496-497). Њихова употреба у језику зависи или од тога како неко замишља појам животиње или од устаљеног семантичког приказивања те животиње у језику: са̂м зооним доводи се у асоцијативносимболичку везу с особом која, према личној процени, исказује одлике које је доводе у везу са том животињом. Зооними откривају посебан свет симболике у култури, па зато поједине животиње имају и по неколико различитих схватања и приказивања сходно народним веровањима и традицији (Арбекова 1977: 44).

У свакој (пот)култури развијен је низ начина њихове употребе, а служба им је двојака: 
a) указују на неправо поређење које тежи ка што реалнијем осликавању, искључиво из перспективе говорног лица, „очевидног“ стања у виду или асоцијације на неко слично, препознато или претходно искуствено. Поређење је субјективни конструкт и у сва три језика исказује се обрасцем:

Verb+(adj.)+copula+zoonym

\section{бити спор као пуж/корњача}

eci/vrapoj si kërmill/breshkë (= „ходати/трчати као црв/корњача)

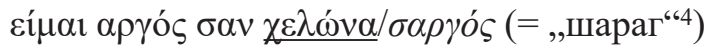

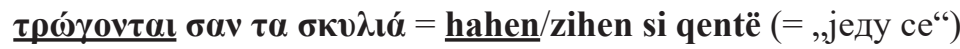

гложе се као керови/пси

Понекад квалификацију чини развијена синтагма:

$$
\begin{aligned}
& \text { бленути/гледати као теле у шарена врата }{ }^{5}
\end{aligned}
$$

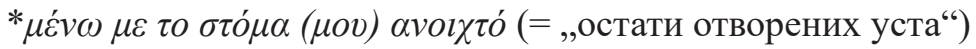

$$
\begin{aligned}
& \text { *shikoj (diçka) me habi/me gojë hapur (= „гледати /шта/ у чуду/отворених } \\
& \text { уста“) }
\end{aligned}
$$

jam si qen i lëshuar nga zinxhiri = бити као пас пуштен с ланца

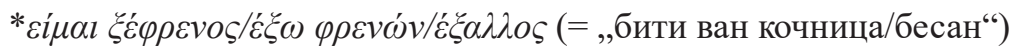

б) посебно квалификују: тиме што свака животиња има карактерне, социјалне, вредносне и моралне људске особине, у сваком језику су се усталили фразеологизми са зоонимима као уобичајеним формама приказивања тих и таквих особина. Квалификације су позитивне и негативне, а без обзира на њих, зооним, денотат, прешао је у конотат, у еуфемизам, изједначивши се или поставши синонимним с неком људском особином.

Зато, када се некоме каже:

$$
\begin{aligned}
& \text { свињо/yovрои́vi /derr! } \\
& \text { магарче/магарчино/үаїоои́рл/gomar! }
\end{aligned}
$$

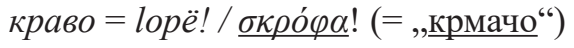

${ }^{4}$ Шараг, врста ситне медитеранске рибе, која није брза ни интелигентна.

${ }^{5}$ Cf. румунски: a se uita/a sta ca vițelul la poarta nouă (= „заборавити се/стајати као теле пред новим вратима“). 
јасан је негативан и увредљив садржај поруке. Тако се особа (субјективно/ објективно) контекстуално „части“ спуштањем на један од најнижих могућих нивоа на друштвеној и културној лествици морала и понашања, а повод за то је начин обедовања (једе као свиња), аљкав или физички изглед (прљав као свиња/дебео као свиња), карактерно понашање (свињо одвратна) или чулна перцепција (заудара/смрди као свиња).

Негативне квалификације су најразличитији типови посебних метафоричних видова исказивања понижавања, вређања и омаловажавања, а „чашћење“ зоонимом једнако је свођењу особе на ту животињу и на проналажење „особина које се препознају као мање људске, које поништавају људско у човеку изједначавајући га са нижим животињским врстама за које је карактеристично одсуство разума, нагонско, неконтролисано понашање“" (Новокмет 2016: 6364). Који се зооними употребљавају као увреда искључиво зависи од културе и традиције, од географског окружења, утицаја из других култура, језика итд. У свакој култури постоје уз опште и посебни стереотипи о животињама који се не сусрећу у другим. Ако се на албанском жени упути у поетском дискурсу комплимент да је nерёrkё e shkruar (= "гуја уписана / шарена"), ова синтагма садржи похвалну поруку. Зато је „бити змија“ изузетна одлика, а цео израз, који истиче кокетну и згодну жену 6 , неуобичајен је због упоређења. Позитивну одлику носи и српски израз имати змијско тело који описује веома згодну жену ${ }^{7}$

За Лича (Leach 1966) идејни концепт заснован на зоонимским увредама лежи на двема категоријама:

a) једна врста ослања се на директну везу између човека и животиња засновану на исхрани. То су припитомљене животиње, најзаступљеније у зоонимском репертоару увреда;

б) друга врста је двојака - осим забрањене везе, посматрано из ланца исхране (неке се не једу/непојмљиве су у исхрани), неке одликује наш тотемски однос према њима. Европљани не једу своје љубимце и не госте се неким дивљим егзотичним животињама (Jay 1999: 196), што не важи за друге народе и за друга поднебља. И унутар европског подручја има разлика: Италијани и Французи једу жабље батаке и пужеве, за народе на Балкану је то неприхватљиво или се тек понегде једу (на Криту су специјалитет).

Зооними као увреде из прве категорије нису јединствени ни по критеријуму јестивости, ни по употреби као негативни квалификатори, па уочавамо три важна типа животиња унутар културно-семантичког простора:

${ }^{6}$ Арапи лепу и згодну жену пореде са камилом, за Французе је то непримерено: за њих је камила тврдоглава и подмукла животиња (Алехина 1978: 159).

7 Људи одувек исказују (страхо)поштовање према змији, јер ,предстаља и велики симбол психичке енергије“ (Aeppli 1943: 382). Минојцу су обожавали „змијску богињу“ ( $\theta \varepsilon \alpha ́$ $\tau \omega v$ ó $\varphi \varepsilon \omega v)$, а Илири (ако претпоставимо да су Албанци њихови потомци) су поштовали култ змије (Stipçeviq 1994: 55-63, Zippel 1877: 18). У албанској народној митологији змије су симболи доброг, те тако треба сагледати указану синтагму. Иначе, ,змија се код Албанаца и данас сматра домаћом животињом која доноси срећу. Када је домаћин спази, поздравља је с великим поштовањем и обасипа благословима“ (Hahn, 1854: 162). 
1. први тип су кућни љубимци за које су везани власници и који их не би ни под којим условима појели (пас, мачка, папагај), а као увреде улазе у категорију негативних квантификатора, уз изузетке (морско прасе, златна рибица);

2. други тип су животиње такође блиске човеку из категорије јестивих (зец, прасе, пиле, коњ, овца, коза, сом, штука), или нејестивих (магарац, мула). Као увреде употребљавају се у најразличитијим контекстима;

3. трећи тип чине остале (мање) познате дивље и егзотичне животиње које људи у Европи и на Балкану не користе у својој исхрани (мрмот, јагуар, тигар, слон, крокодил), а неке држе као љубимце (коала, игуана, питон, веверица). Зависно од језика, тек поједини зооними употребљавају се као негативни квалификатори.

И код дивљих животиња постоје две главне категорије такође засноване на јестивости - мада су неке одавно прихваћене у исхрани (фазан, препелица, јелен), превагу односи много већи број нејестивих (вук, лисица, гавран, миш, медвед). Нису ни сви називи ових животиња опредељени као негативни квалификатори - уз оне препознатљиве у другим језицима, у сваком језику постоји и посебна листа ових зоонима карактеристична за сваки народ и културу. По броју зоонима у увредама у сва три балканска језика, називи домаћих животиња су заступљенији у односу на називе дивљих, што је очекивано:

грчки - 16: 5; албански - 15: 5; српски - 15: 4

Најмању заступљеност као негативи квалификатори имају називи познатих инсеката и риба.

Увреде са зоонимом настају када човек пресликава препознати негативни модел понашања неке познате домаће/дивље животиње у свој свет, чиме одлика понашања те животиње постаје уврежени стереотип. Зато се не употребљавају лексеме ЖИРАФА:

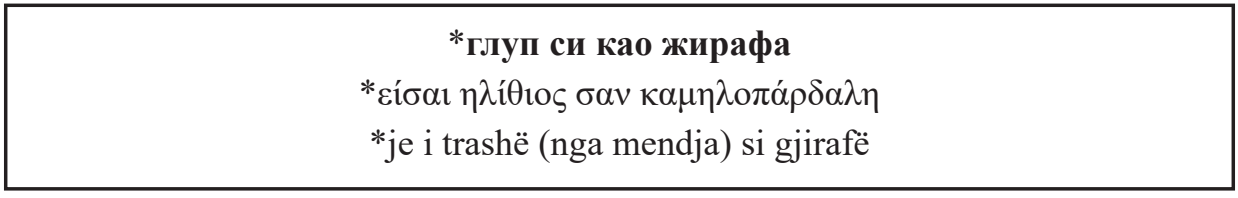

или СИПА:

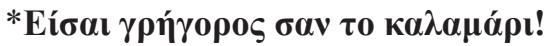 \\ *Брз си као лигња! \\ * Je i shpejtë si kallamar!}


у изразима, јер се контекстуално значење не би правилно разумело. Ако се обратимо некоме:

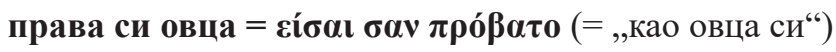

*çfarë trapi je!(=,ккакав сплав си“)

тада постоји јасна конотативна алузија на добро познати културни стереотип. Зоонимске увреде ослањају се на културне дефиниције истакнутих својстава приписаних познатим животињама за које се претпоставља да имају паралеле са људским карактеристикама. Зато ниједан говорник неког од разматраних језика не помишља да некога назове туканом или мрмотом ради увреде, пошто су ови називи неспецифични за (европско и) балканско географско подручје и нису укључени ни у традиционалну зоонимију ових језика ни у зоонимски негативни културолошки репертоар увреда. Тек у новије време се примећује спорадична појава егзотичних зоонима.

\section{4. Зооними као увреде}

Увреда је вид чина и/или нека изговорена/написана реч која наноси штету, душевну бол, неправду, срамоту, чиме се хотимично или несмотрено повређује нечије достојанство. Кривични законик Републике Србије, 170. члан, одређује увреду као кривично дело уперено против нечије части и угледа (КЗ 2009: 59) и за то се прописује одговарајућа новчана казна. Циљ увреда је да онога на кога се односе омаловаже и прикажу у друкчијем светлу у односу на ону представу коју лице има о себи. Онако како себе доживљавамо представља нашу моралну категорију части, и зато припада субјективном пољу, а углед је објективно поље и тиче се нашег моралног оличења пред другима, како нас други виде, доживљавају. Највећи број нанесених увреда су претежно вербалне.

Увреде са зоонимским квалификаторима су посебна лексичка и семантичка категорија, а тиче се светоназора једног народа, његове културе, традиције и веровања. Право разумевање овакве лексичке подврсте дотиче се и прагматике: како су у језику похрањена бројна сазнања, он функционише попут сложеног енциклопедијског система (De Carlo 1998: 101-102 и даље) који се активира сваки пут у говору када покушавамо да изразимо увреду. За Галисон и Пурен (Galisson-Puren 1999: 188-189), то је подударан (препознатљив) лексички слој ${ }^{8}$, приближно исти лексички фонд формиран према интернационалним културним, гастрономским, цивилизацијским, географским и моралним чиниоцима који су условили избор и устаљење најосновнијег лексичког фонда увреда са зоонимима као компонентама:

\footnotetext{
${ }^{8}$ Обрадили су само француски, енглески, немачки и руски.
} 


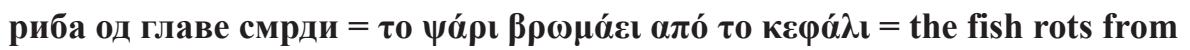
the head down $=$ der Fisch stinkt vom Kopf her $=$ fejétöl büzlik a hal $=$ peshku qelbet nga koka

$\pi \varepsilon ́ \varphi \tau о v v \sigma \alpha v \tau \imath \varsigma \mu v ́ \gamma \varepsilon \varsigma=$ падају као муве = drop like flies

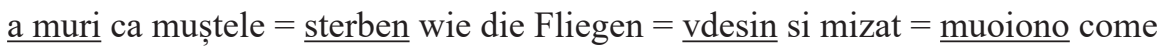
mosche (=,„умиру“)

поклоњеном коњу не гледају се зуби = дарёному коню в зубы не смотрят = kalit të dhuruar mos i shiko/numëro dhëmbët = ajándék lónak ne nézd a fogát calul de dar nu se caută la dinți/色 gură $=$ do not look a gift horse in the mouth $=$ a caval donato non si gurada in bocca

Варијација је структурно видљива у избору глагола (смрдети/трулети; падати/умрети) или лексичких јединица (зуби/уста). Поменути аутори не разматрају могућност међусобних утицаја између различитих народа који су се одразили на избор и устаљење истих зоонима у увредама, што је омогућило преношење истог негативног смисла истим конструкцијама. Примери оваквих међујезичких утицаја и преношења истог семантичког оквира унутар балканског језичког ареала илуструју наредни фразеологизми семантички и структурно подударни:

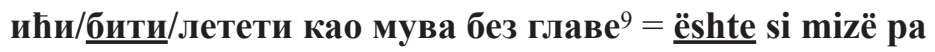 kokë/krye $=$ akar egy fej nélküli légy ${ }^{10}$}

a se învârti ca o muscă fără cap $\left(=\right.$, ,окретати ce $\left.{ }^{66}\right)=$ върти се като муха без глава ${ }^{11}$

бити као магарац међ овцама ${ }^{12}=$ a fi ca măgarul între oi $=$ hiu ca gumarlu tu/anamisa di $0^{13}=$ juhok között a szamár ${ }^{14}$

*si dhia në mes të dhenve (= „као коза међу овцама“)

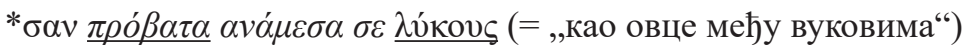

уз очекивана структурна одступања, лексичка (други пример: у конструкцијама на албанском и грчком употребљени су други зооними /козе/овце; овце/вуко-

\footnotetext{
${ }^{9} \mathrm{Cf}$ : matt wie eine Fliege.

${ }^{10}$ Мађарски.

${ }^{11}$ Бугарски.

${ }^{12}$ Наведени фразеологизам се чује у Војводини, у Србији (бити) као врана међу голубовима.

${ }^{13}$ Аромунски.

${ }^{14}$ Мађарски.
} 
ви/ или глаголи), као и нулте структурно-семантичке еквиваленције, пошто се у сваком балканском језику фразеолошка слика на исту семантичку поруку формира или друкчијом фразеологизацијом или нефразеолошки.

Избором из синонимних варијаната говорно лице своју поруку стилски и семантички боји, подвлачећи субјективни став и осећања уз постизање додатног афективног ефекта који као да се „подешава“ према непосредној ситуацији:

\section{бити глуп(а) као ћурка/гуска/*}

[është] mendjelehtë si miza/trupi gjel, truri mel

(= „глуп као мува“/,„тело петла, мозак просо“)

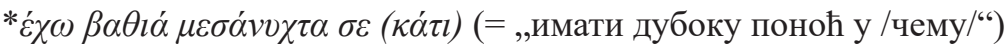

\section{ради као коњ/мазга/* щрнащ}

punon si derr/kalë/gomar/ka15/ari (= „свиња/коњ/магарац/во/медвед“)

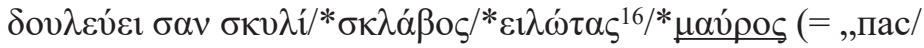
*роб/*хелот/*црнац“)

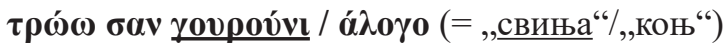

ha si ariu/derr (= „медвед“/,,свиња“ $)=$ јести као свиња

Укупан број забележених „интернационалних увреда“ у грчком, албанском и српском у фразеологизмима састављеним од зооонимских негативних квалификатора је релативно симболичан. Највећу превагу односе идиотипични, карактеристични за сваки језик понаособ, а потом слични/подударни с фразеологизмима у разматраним језицима. Ових је нешто више од интернационалних. По језицима, то изгледа овако:

\begin{tabular}{|l|c|c|c|c|c|}
\hline \multicolumn{1}{|c|}{ језик } & $\begin{array}{c}\text { интер- } \\
\text { национални }\end{array}$ & $\begin{array}{c}\text { домаћи } \\
\text { идио- } \\
\text { типични }\end{array}$ & $\begin{array}{c}\text { домаћи } \\
\text { слични/ } \\
\text { подударни } \\
\text { с грчким }\end{array}$ & $\begin{array}{c}\text { домаћи } \\
\text { слични/ } \\
\text { подударни } \\
\text { с албанским }\end{array}$ & $\begin{array}{c}\text { домаћи } \\
\text { сличн/ } \\
\text { подударни } \\
\text { са српским }\end{array}$ \\
\hline грчки & 25 & 79 & $/$ & 16 & 18 \\
\hline албански & 31 & 81 & 21 & $/$ & 32 \\
\hline српски & 22 & 83 & 14 & 29 & $/$ \\
\hline УкУПнО & 78 & 243 & 35 & 45 & 50 \\
\hline
\end{tabular}

${ }^{15}$ Cf.: работать/трудиться как вол.

${ }^{16}$ Хелот, роб у Спарти. 
Галисон и Пурен указују и да увреде изведене од зоонима поседују заједничку културну и моралну вредност за све говорнике једног језика, невезано за територију где живе као и на евентуалне (могуће) упливе из других језика. Ово је суштинска одлика, јер огроман број оваквих увреда чине исконски део наслеђене лексике који није подложан честим променама ни утицајима из других језика.

Без обзира на то о каквим је зоонимским квалификаторима реч као и да ли припадају позитивном или негативном пољу, Неси истиче да су „у свакој култури поједини називи животиња стриктно везани с одређеним атрибутима те зато постоји општи договор о томе који су то. То не значи да су овакве метафоре 'мртве'; напротив, оне су живи део језика и често се употребљавају захваљујући своме снажном ефекту“ (Nesi 1995: 274).

\section{5. Класификација негативних зоонимских квалификатора у грчком, албанском и српском}

Једна од могућих подела зоонимских негативних квантификатора у грчком, албанском и српском може бити путем рода без обзира на пол. Уочавамо четири подтипа који се могу сматрати увредама у најширем погледу.

a) Прва подгрупа тиче се углавном мушкараца, понекад жена, сходно контексту. Најчешћа је конструкција састављена од именског дела предиката и копуле:

\begin{tabular}{|c|c|c|}
\hline грчки & албански & српски \\
\hline 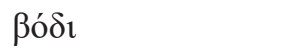 & buall & бик/биво \\
\hline$\sigma \alpha \lambda \imath \gamma \kappa \alpha ́ \rho 1 / \chi \varepsilon \lambda \omega \dot{v} \alpha$ & kërmill/breshkë & пуж ${ }^{17} /$ корњача \\
\hline ко́кораऽ & gjel/këndes/kaposh & певац \\
\hline 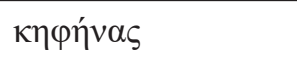 & brumbull & трут \\
\hline$\varepsilon \lambda \varepsilon ́ \varphi \alpha \nu \tau \alpha \varsigma$ & elefant & слон/слоница \\
\hline$\tau \sigma i ́ p o \varsigma / \tau \sigma ı р о \pi о v ́ \lambda \imath$ & gërdallë & сарага \\
\hline$(\rho \eta ́ \sigma o \varsigma / \lambda v ́ \gamma \kappa \alpha \varsigma)^{18}$ & rrëqebull & рис \\
\hline 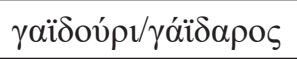 & gomar/kërriç & магарац/сивоња \\
\hline 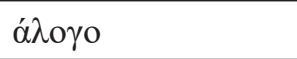 & $1^{19}$ & коњ \\
\hline$\pi \alpha \pi \alpha \gamma \alpha \dot{\lambda} \mathrm{o}$ & papagall & папагај/папига \\
\hline$\tau \rho \alpha ́ \gamma o \varsigma$ & dash/cjap & јарац \\
\hline$\alpha \lambda \varepsilon \pi \sigma v^{\prime}$ & dhelpër & лисац \\
\hline
\end{tabular}

\footnotetext{
${ }^{17}$ Метафорички: ленштина/сnораћ.

${ }^{18}$ Иако постоје одговарајући зооними у грчком, у овом контексту се не употребљавају.

19 У албанском kalë (= “коњ”) има само позитивну конотацију.
} 


\begin{tabular}{|l|l|l|}
\hline$\beta \rho \alpha \delta \dot{\pi} \pi \circ \delta \alpha \varsigma$ & përtac & лењивац \\
\hline$(\alpha \rho \kappa о v ́ \delta \alpha)$ & ari & медвед \\
\hline
\end{tabular}

За разлику од албанског и српског, у грчком је довољно употребити зооним

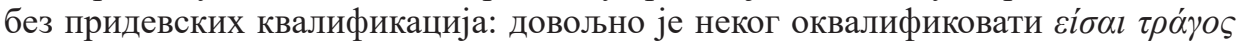
и порука је јасна. У српском и албанском влада други принцип (додају се лексички елементи) ${ }^{20}$ чиме се описно подиже степен вређања (пејоративности) и доживљавања друге особе (cf: матори/одртавели јараи = cjap plak).

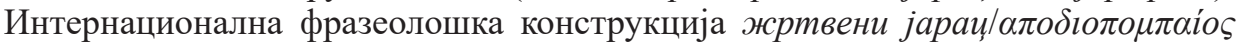
$\tau \rho \alpha ́ \gamma o \varsigma$ се у албанском исказује на други фразеолошко-лексички начин - dashi $i$ kurbanit (= „курбански ован“) $)^{21}$.

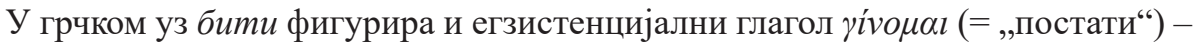

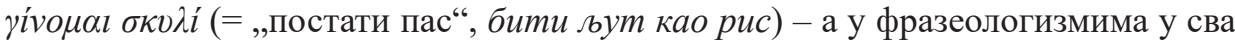
три језика сусрећу се различити глаголи:

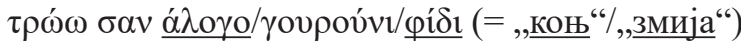

$$
\begin{aligned}
& \text { јести као свиња }=\text { ha si derr }
\end{aligned}
$$

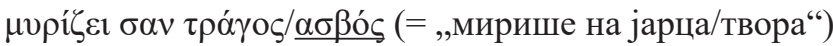

смрди као твор $=($ është $)$ qelbës i fëlliqur (= ,[бити] смрдљиви твор“)

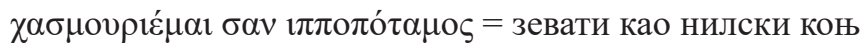

$$
\begin{gathered}
\text { ecën si ari (= „хода као медвед“) } \\
\text { *гега се }
\end{gathered}
$$

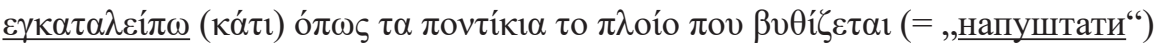
бежати као мишеви са брода који тоне = ikin si minjtë nga anija që fundoset палаца језиком као змија

*nuk i pushon goja (= „не стају јој уста“)

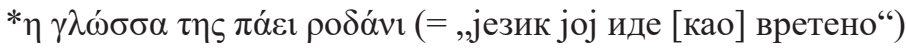

qeni leh atje ku ha (= „пас лаје тамо где једе“)

*знати/видети одакле ветар дува $=(\pi \alpha ́ \omega)$ о́лоv $\varphi v \sigma \alpha ́ \varepsilon 1 ~ о ~ \alpha ́ v \varepsilon \mu о \varsigma^{22}$ реч.

${ }^{20}$ Из примера се види да су то придеви и именице. Понекад то може бити ма која именска

${ }^{21}$ Cf. немачки, мађарски Sündenbock/bünbak (= ,jарац за грехове“), руски козёл отпущения (=, ,јарац за опрост грехова“).

${ }^{22} \mathrm{Cf}$. албански синоним: kthen gunën (krahët) nga fryn era (= „окреће гуњ/рамена одакле дува ветар“"). 
Ономатопејски глаголи такође служе негативном квалификовању, а допунски део носи поређење с одговарајућим зоонимом:

лаје/режи као пас $=\gamma \alpha \beta \gamma i \zeta \varepsilon 1 / \gamma \rho v \lambda i \zeta \zeta \varepsilon \iota ~ \sigma \alpha \nu ~ \sigma \kappa v \lambda i ́=1$ eh/hungëron si qen

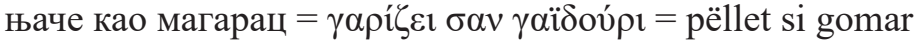

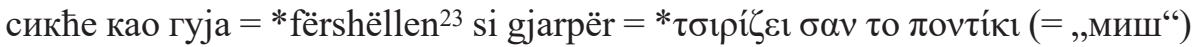

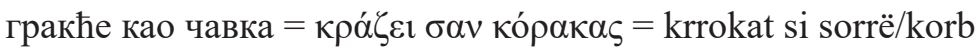

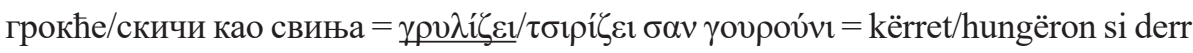

Понекад је именица у вокативу: у српском тада није сама, већ јој следи допуна преко анафоричног нумерала један/једна/једно који као да надомешта глагол употпуњавајући целокупан смисао исказу и пружајући му јачину у изражајности. Ово је посебна граматичко-стилска карактеристика у односу на грчки и албански (кољу један/стоко једна/псето једно). За албански је карактеристично и то да се уз именицу у вокативу може наћи адмиратив глагола jam (gomar qenke! = баш си магарац!).

b) Друга група зоонимских негативних квалификатора упућује се махом женској популацији (њих је незнатно више од претходних):

\begin{tabular}{|c|c|c|}
\hline грчки & албански & српски \\
\hline$\alpha \gamma \varepsilon \lambda \alpha ́ \delta \alpha$ & lopë & крава \\
\hline$\gamma \alpha \lambda ı \alpha ́ v \tau \rho \alpha$ & $1^{24}$ & I \\
\hline$\gamma \alpha \lambda \circ \pi \circ{ }^{\prime} \lambda \alpha$ & bibë & ћурка \\
\hline$\kappa \alpha \mu \eta^{\prime} \lambda \alpha^{25}$ & 1 & камила \\
\hline 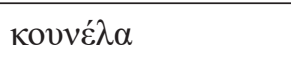 & lepurushë & зечица \\
\hline$\sigma \kappa v ́ \lambda \alpha$ & bushtër/qene & кучка/куја \\
\hline 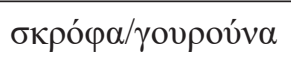 & derre/dosë & крмача/свиња \\
\hline 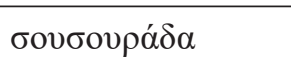 & $1^{26}$ & l \\
\hline$\varphi \alpha ́ \lambda \alpha i v \alpha$ & dosë & крмача/свиња/крава \\
\hline$\varphi о \rho \alpha ́ \delta \alpha$ & pelë & кобила \\
\hline
\end{tabular}

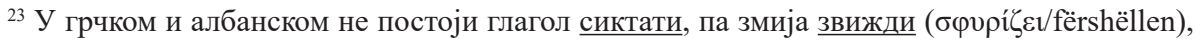
односно у грчком „фијуче“, у албанском „шишти“, „пишти“ (cf.: писну гуја љута).

${ }^{24}$ Преводни еквивалент је без зоонима - брбљивица/ лајавица (буквално: „шева“).

${ }^{25}$ Као увреда: „габор“.

${ }^{26}$ Преводни еквивалент искључује зооним - успијуша/намигуша. 


\begin{tabular}{|l|l|l|}
\hline$\varphi \omega ́ \kappa 1 \alpha$ & $/^{27}$ & $/$ \\
\hline$\chi \eta ́ v \alpha$ & patë & гуска \\
\hline
\end{tabular}

с) Трећа група зоонима разликује род, мушки и женски:

\begin{tabular}{|c|c|c|}
\hline грчки & албански & српски \\
\hline$\alpha \lambda \varepsilon \pi \circ{ }^{\prime}$ & dhelpër & лисац/лисица \\
\hline 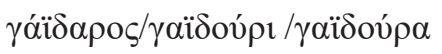 & gomar/gomaricë/gomare & магарац/магарица \\
\hline 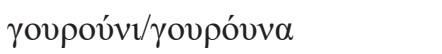 & derr/dosë & вепар/свиња/крмача \\
\hline 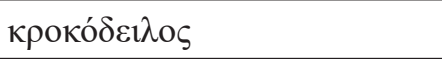 & krokodil & крокодил/крокодилка ${ }^{28}$ \\
\hline 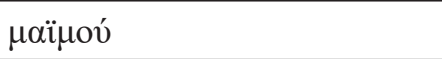 & majmun/majmune & мајмун/мајмуница \\
\hline$\mu o v \lambda \alpha ́ \rho \mathrm{\gamma} / \gamma \alpha \ddot{ } \delta \mathrm{\delta} o v \rho \alpha$ & mushkë & мазга/мула \\
\hline$\pi \alpha$ óvi & pëllua & паун/пауница \\
\hline$\sigma \kappa v ́ \lambda \circ \varsigma / \sigma \kappa v ́ \lambda \alpha$ & qen/bushtër/qene & псето/џукела/кучка \\
\hline$\tau \rho \alpha ́ \gamma о \varsigma / \kappa \alpha \tau \sigma i ́ \kappa \alpha$ & cjap/dhi & јарац/коза \\
\hline
\end{tabular}

d) Четврта група су родно неутрални зоонимски негативни квалификатори који су између увреда и разних „почасних“ комплимената, понекад у аугментативу, а метафорички описују нечије личне карактеристике:

\begin{tabular}{|c|c|c|}
\hline грчки & албански & српски \\
\hline$\sigma \kappa о v \lambda \eta ́ \kappa 1$ & krimb & црв \\
\hline 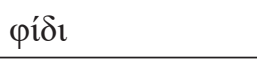 & gjarpër/nepërkë & змија/гуја \\
\hline кó $\tau \alpha$ & pulë & кокош(ка) \\
\hline$\chi \varepsilon \lambda \omega ́ v \alpha$ & breshkë & корњача \\
\hline$\pi \rho o ́ \beta \alpha \tau o$ & dele & овца \\
\hline$\tau \sigma 1 \mu \pi \mathrm{oú} \rho t$ & këpushë & крпељ \\
\hline$\psi v ́ \lambda \lambda o \varsigma$ & plesht & бува \\
\hline$\mu о \sigma \chi \alpha ́ \rho 1$ & viç & теле \\
\hline 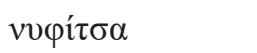 & bukël & ласица \\
\hline$\tau \sigma \alpha \kappa \alpha ́ \lambda l$ & çakall/ujk & (*шакал)/курјак \\
\hline
\end{tabular}

${ }^{27}$ Фஸ́кı (= „фока“): „прасица/крмача“.

28 У грчком сленгу крокодил означава „незајажљиву/грамзиву особу“. У разговору у српском се често чује указани облик женског рода, граматички још неустаљен. 


\begin{tabular}{|c|c|c|}
\hline$\beta \delta \varepsilon \dot{\varepsilon} \lambda \lambda \alpha$ & shushunjë & пијавица \\
\hline$\psi \varepsilon i ́ p \alpha$ & morr & вашка/гњида \\
\hline 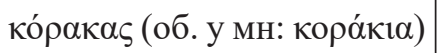 & laraskë/sorrë & чавка/сврака \\
\hline$\sigma \tau \rho \varepsilon i ́ \delta 1$ & tartabiqe & стеница \\
\hline ópvio & larash & лешинар \\
\hline$\chi \alpha \mu \varepsilon \lambda \alpha i \omega v / \chi \alpha \mu \varepsilon \lambda \varepsilon i ́ o v \tau \alpha \varsigma$ & kameleon & камелеон \\
\hline$\chi \tau \alpha \pi$ ó $\delta 1$ & oktapod & хоботница \\
\hline 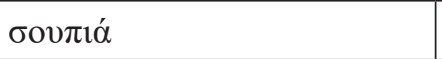 & $\left(*_{\text {sepje }}\right)$ & (*сипа) \\
\hline$\mu \alpha v \alpha ́ \rho t^{29}$ & I & *дебела свиња \\
\hline$\kappa \alpha \rho \alpha \kappa \alpha ́ \xi \alpha^{30}$ & / & *крава/коза матора \\
\hline
\end{tabular}

Иако се сви наведени зооними из овог прегледа употребљавају идентично у сваком језику, укажимо и на неке разлике. Грчки зооним жєі́ $\alpha$ не употребљава у се значењу „улизица“, како је то уобичајено у српском, већ „цепидлака“, а у албанском има и значење „досадна особа“, као у српском. У грчком и српском се под октоподом подразумева неко ко не уме да се одвоји од другог, у албанском означава особу која се бави мутним радњама и ради на штету других иза леђа. У грчком овај зооним фигурира у конструкцији $\theta \alpha \sigma \varepsilon \chi \tau \eta \pi i \sigma \omega / \kappa o \pi \alpha-$

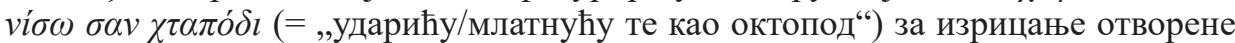
претње (= „оплавити кога од батина“). По нама, у ову групу зоонимских

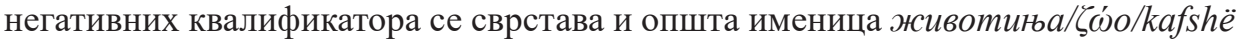

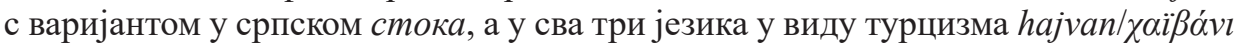
с метафоричком конотацијом „заосталог“, „припростог“ човека.

\section{6. Закључна разматрања}

У раду смо се у најширим цртама посветили зоонимима који функционишу као негативни квалификатори у грчком, албанском и српском. Како се ове лексеме налазе и у фразеологизмима, осврнули смо се укратко и на неке од њих. У сва три језика превагу односе познати називи животиња, домаћих и дивљих. У интернационалне негативне зоонимске квалификаторе сврставају се и све ономатопејске конструкције с допуном у виду придевске поредбене синтагме. Заједничко за сва три језика (и остале европске) јесте идентичан образац формирања негативних (и позитивних) карактеризација: обично је

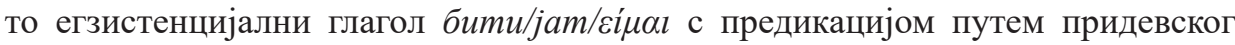
поређења с одабраним зоонимом. Понекад се унутар именског дела предиката јавља незнатно синтаксичко проширење, те осим простих конструкција (бити

\footnotetext{
${ }^{29}$ Означава младо (тј. “сисанче“) овце, козе, краве које се посебно храни ради клања.

${ }^{30}$ Буквално „сврака“.
} 
спор као пуж), постоје и нешто сложеније (бити као слон у стаклари). У сва три језика се у новије време сусрећу и називи разних егзотичних животиња који још нису ушли у фразеологизацију и више су одлика говорног него писаног (књижевног) дискурса. У грчком се појављују зооними неспецифични за албански и српски: или су непознати, због географског поднебља, или нису прихваћени као могући репрезенти појединих појава, што значи да је симболика зоонима од језика до језика функционална или нефункционална (Sperber 1999: 149). Слободна комутација зоонимских лексема не ремети семантички поруку (козо/гуско/краво/кобило/једна/!), а варијација лексема унутар познатог контекста интензивира увреду и стилски је нијансира, „подешава“ према личном ставу говорног лица и његовим тренутним осећањима. Вољно (намерно/ свесно) бирајући онај зооним из њему познатог фундуса, говорно лице својим „коначним решењем“ постиже циљ: да што јаче повреди саговорника, истовремено подижући степен омаловажавања и вређања.

Уочене разлике указују на то да су на све три лингвокултуролошке језичке заједнице утицали и најразличитији унутрашњи и спољашњи културни, друштвени, морални, религијски, историјски, језички и други елементи из (суседног/ суседних) језика, култура и друштава који су, сваки за себе, обликовали зоонимску слику у сваком од разматраних језика понаособ. Заједничко за сва три језика је то што „мотивација за метафорички пренос значења [зоонима] зависи од величине, начина исхране, карактера и/или интелигенције адресата“" (Halupka-RešetarRadić 2003: 1900). Негативни зоонимски квалификатори деперсонализују особу, пуко је сводећи, према контексту, на најнижи морални и социјални ниво, на ниво животиње чиме се,„људи идентификовањем са животињама најчешће деградирају а зоонимска метафора је учестало средство експресивног истицања непожељних људских карактеристика“" (Новокмет 2017б: 106). Употребљени самостално или фразеолошки, зоонимски негативни квалификатори, симболични називи упућени као увреде и карактеризације, семантички су веома експлицитни. Надевањем одговарајућег зоонима, уз вређање, уочава се ниво друштвене и моралне дискриминације, врста предрасуда, стереотипа и место на које се неко спушта. Ове увреде се споро заборављају ${ }^{31}$, јер зооними пре смањују него што повећавају физичку и менталну дистанцу између животиња и људи.

\section{Цитирана литература}

Aeppli, Ernst. Der Traum und seine Deutung. Zürich: Eugen Rentsch-Verlag, 1943.

Алехина, Анфиса И. Семантические группы во фразеологии современного англйиского языка. Минск: Издательство «Высшая школа», 1978.

[Alekhina, Anfisa I. Semanticheskie gruppy vo frazeologii sovremennogo anglĭiskogo iazyka. Minsk: Izdatel'stvo «Vysshaia shkola», 1978]

Арбекова, Татьяна И. Лексикология английского языка (практический курс). Москва: «Высшая школа», 1977.

[Arbekova, Tat'iana I. Leksikologiia anglĭiskogo iazyka (prakticheskĭi kurs). Moskva: «Vysshaia shkola», 1977]

31 Лутер: „Ништа се не заборавља спорије од увреде, а ништа брже од доброчинства“ (Nichts wird langsammer vergessen als eine Beleidigung und nichts eher als eine Wohltat). 
Budny, Rosana. Phraseological Units With Zoomyms in Bilingual School Dictionaries (Portuguese-English) and the Issue of Equivalences. Alfa, rev. linguist, Vol. 61, No. 2 (May/August 2017), 2017: 495-509.

Bugarski, Ranko. Lingvistika o čoveku (drugo, dopunjeno izdanje). Beograd: Prosveta, 1983.

Bugarski, Ranko. Jezik i kultura. Beograd: Biblioteka XX vek, 2005.

De Carlo, Maddalena. L`intercultural. Paris: Editions Seuil, 1998.

Драгићевић, Рајна. Вербалне асоцијације кроз српски језик и културу. Београд: Друштво за српски језик и књижевност, 2010.

[Dragićević, Rajna. Verbalne asocijacije kroz srpski jezik i kulturu. Beograd: Društvo za srpski jezik i književnost, 2010]

Ellis, Nick. „Vocabulary Acquisition: Word Structure, Collocation, Word-Class and Meaning. “[In:] Schmidt, Norbert, McMarthy, Michael. (Eds.) Vocabulary-Description, Acquistion and Pedagogy, Cambridge: CUP, 1997: 122-139.

Galisson, Robert, Puren, Christian. La Formation en Questions. Paris: CLE International, 1999.

Гортан-Премк, Даринка. Полисемија и организација лексичког система у српском језику. Београд: Завод за уџбенике, 2005.

[Gortan-Premk, Darinka. Polisemija i organizacija leksičkog sistema u srpskom jeziku. Beograd: Zavod za udžbenike, 2005]

Jay, Timothy. Why We Curse - a Neuro-psycho-social Theory of Speech, Amsterdam: John Benjamin Publishing, 2000.

Јовановић, Иван. „Лексема cheval/коњ у француској и српској фразеологији“. [У:] Иван Јовановић (ур.) Језици и књижевности у контакту и дисконтакту (тематски зборник радова Наука и савремени универзитет 7). Књига 1. Ниш: Филозофски факултет, 2018: 55-67.

[Jovanović, Ivan. „Leksema cheval/konj u francuskoj i srpskoj frazeologiji“. [U:] Ivan Jovanović (ur.) Jezici i književnosti u kontaktu i diskontaktu (tematski zbornik radova Nauka i savremeni univerzitet 7). Knjiga 1. Niš: Filozofski fakultet, 2018: 55-67]

Lavedan, Pierre. Dictionnaire illustré de la mythologie et des antiquités grecques et romaines. Paris: Librairie Hachette, 1931.

Leach, Edmund R. „Anthropological Aspects of Language: Animal Categories and Verbal Abuse." Y: Erich H. Lennenberg (Ed.) New directions in the study of language, Cambridge: MIT Press, 1964: 23-63.

McLuhan, Marshall. Understanding Media: The Extensions of Man. MIT Press, 1994.

Miller, George 2 . „Images and models, similes and metaphors”. [In:] Ortony, Andrew (ed.) Metaphor and Thought. Cambridge: CUP, 1993: 357-400.

Moon, Rosamund. Fixed Expressions and Idioms in English. A Corpus-Based Approach. Oxford: OUP, 1998.

Nesi, Hilary. „A modern bestiary: a contrastive study of the figurative meanings of animal terms." ELT Journal Volume 49/3 (July 1995), 1995: 272-278.

Новокмет, Слободан. „Метафорична значења лексема из лексичко-семантичке групе назива за псе која се односе на људске особине“. Књижевност и језик LXIII/1-2, 2016: 49-66.

[Novokmet, Slobodan. „Metaforična značenja leksema iz leksičko-semantičke grupe naziva za pse koja se se odnose na ljudske osobine“. Književnost i jezik LXXIII/1-2, 2016: 49-66]

Новокмет, Слободан. „Метафорична значења животињских назива које се односе 
на човека неморалних особина у српском језику. Српски језик XXII, 2017a: 534 554.

[Novokmet, Slobodan. „Metaforična značenja životinjskih naziva koje se odnose na čoveka nemoralnih osobina u srpskom jeziku“. Srpski jezik XXII, 2017a: 534-554]

Новокмет, Слободан. „Метафорична значења животињских назива која се односе на човека ниске интелигенције у српском језику“. Зборник Матице српске за филологију и лингвистику, 60/1, 2017б: 103-119.

[Novokmet, Slobodan. „Metaforična značenja životinjskih naziva koja se odnose na čoveka niske inteligencije u srpskom jeziku“. Zbornik Matice srpske za filologiju i lingvistiku, 60/1, 2017b: 103-119]

O'Konel, Mark, Eri, Rejdž. Ilustrovana enciklopedija znakova i simbola. Identifikacija i analiza vizuelnog rečnika koji formuliše naše misli i diktira reakcije na svet oko nas. Beograd: JRJ, 2007.

Saville-Troike, Muriel. An Ethnography of Communication. Oxford: Blackwell, 1982.

Sperber, Dan. (1996). "Why are perfect animals, hybrids, and monsters food for symbolic thought?" Y: Method \& Theory in the Study of Religion 8-2, 1996: 143-169 (Revised English version of "Pourquoi les animaux parfaits, les hybrides et les monstres sont-ils bons à penser symboliquement?" L'Homme, XV/2, 1975: 5-24).

Stipçeviq, Aleksandër. Interpretime Albanologjike. Shkup: Flaka e Vëllazërimit, 1994. Hahn, Johann Georg von. Albanesische Studien. Band 1. Leipzig: F. Mauko, 1854.

Halupka-Rešetar, Sabina, Radić, Biljana. Animal names used in addressing people in Serbian. Journal of Pragmatics 35 (December 2003), 2003: 1891-1902.

Zippel, Gustavus. Die römische Herrschaft in Illyrien bis auf Augustus. Leipzig: B. G. Teubner, 1877.

\section{Извори}

Gjevori, Mehmet. Frazeologjizma të gjuhës shqipe. Prishtinë: Rilindja, 1988.

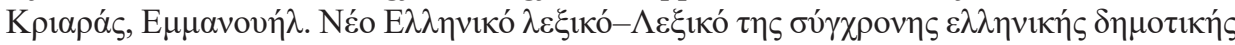

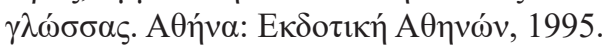

[Kriarás, Emmanoíl. Néo Ellinikó lexikó-Lexikó tis sínkhronis ellinikís dimotikís glóssas. Athína: Ekdotikí Athinón, 1995]

Matešić, Josip. Frazeološki rječnik hrvatskoga ili srpskoga jezika. Zagreb: Školska knjiga, 1982.

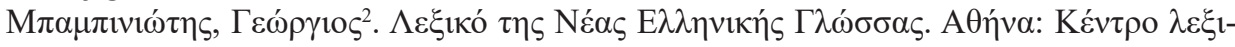

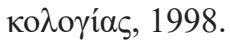

[Bampiniótis, Yeóryios². Lexikó tis Néas Ellinikís Glóssas. Athína: Kéntro lexikoloyías, 1998]

Мутавџић, Предраг. Грчко-српски речник идиома. Београд: Јасен, 2007.

[Mutavdžić, Predrag. Grčko-srpski rečnik idioma. Beograd: Jasen, 2007]

Оташевић, Ђорђе. Фразеолошки речник српског језика. Нови Сад: Прометеј, 2012.

[Otašević, Đorđe. Frazeološki rečnik srpskog jezika. Novi Sad: Prometej, 2012]

Речник српскохрватског књижевног језика (1-6). Нови Сад: Матица српска, 1995.

[Rečnik srpskohrvatskog književnog jezika (1-6). Novi Sad: Matica srpska, 1995]

Речник српскохрватског књижевног и народног језика САНУ (1-). Београд: Институт за српски језик САНУ, 1959-.

[Rečnik srpskohrvatskog književnog i narodnog jezika SANU (1-). Beograd: Institut za 
srpski jezik SANU, 1959-]

Тєүó

[Tegópoulos-Phitrákis ${ }^{10}$. Ellinikó lexikó. Athína: Ekdósis Armonía, 1995]

Fjalor i Gjuhës Shqipe. Tiranë: Akademia e Shkencave e Shqipërisë, 2006.

Fjalor Frazeologjik i Gjuhës Shqipe. Tiranë: Akademia e Shkencave e Shqipërisë, 1999.

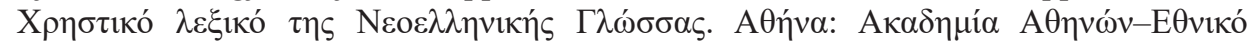

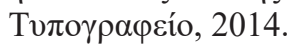

[Khristikó lexikó tis Neoellinikís Glóssas. Athína: Akadimía Athinón-Ethnikó Tipographío, 2014]

\section{Online речницุи}

http://www.shkenca.org/content/view/142/27/

http://www.greek-language.gr/greekLang/modern_greek/tools/lexica/triantafyllides/

\section{Скраћенице}

КЗ: Кривични законик Републике Србије. Београд: Службени гласник, 2009. 
Predrag Mutavdžić

Merima Krijezi

\title{
ON ZOONYMS WITH AN OFFENSIVE CONNOTATION IN ALBANIAN, GREEK AND SERBIAN
}

\begin{abstract}
Summary
This paper is dedicated to zoonyms as negative qualifiers with an offensive semantic content in three contemporary Balkan languages - Albanian, Greek and Serbian. Analyzed herein is their independent use, unconditioned by phraseological structures, as well as their use within idiomatic expressions. In all three languages there is a far smaller percentage of common international phraseological images, whereas each of the languages considered is characterized by a specific indigenous, that is to say, idiotypical phraseological image. If we consider the total number of animal phraseologisms which appear in insults in the mentioned languages, the names of domesticated animals as opposed to wild ones are represented in the following ratios: Greek 16:5; Albanian 15:5; Serbian 15:4. The least represented of all animal phraseologisms recorded are names of insects and fish. One of the possible classifications of negative zoonymic quantifiers in Greek, Albanian and Serbian is gender-based and lacks sex-related markedness. Such classification is characterized by four subtypes, which may be considered insults in the broadest sense. Animal phraseologisms are also analyzed as stereotypical images or as negative models of human behavior, modeled on behavior of some domesticated/wild animals that exist in the human environment.

Keywords: zoonyms, insults, characterization, classification, phraseologisms, Albanian, Greek, Serbian.
\end{abstract}

